\title{
Review
}

\section{Simone de Beauvoir and the politics of ambiguity}

\author{
Sonia Kruks \\ Oxford University Press, Oxford, 2012, 181pp., \$29.95, ISBN: 978-0195381436
}

Contemporary Political Theory (2014) 13, e1-e4. doi:10.1057/cpt.2013.29

Simone de Beauvoir spent much of her writing life, across many genres, criticizing ways of living and of thinking that narrow the scope and grasp of human freedom. She also, through her life example, created space for alternatives. Beauvoir has sometimes erroneously been understood as theorizing freedom solely as an individual good or as the individual's responsibility, when in fact she repeatedly demonstrates conditions of freedom as both collective and situated. Theorizing concrete conditions of freedom as constituted in and through collective life, Beauvoir's work draws our attention to the impact on individuals of different political realities and contexts (capitalism, patriarchy, communism, occupation, colonialism, socialism), the harm in political meanings of various forms of embodiment (race, age, gender), and the direct and indirect effects of oppression and domination on individuals in multiple political contexts. Her oeuvre reveals that she was, in fact, preoccupied with politics broadly understood, or we might say that Beauvoir helps us recognize certain events, situations and ideas, as well as forms of speech, address and language as political even when we do not recognize them as such at first glance.

However, even if we define politics more narrowly, we can turn at random to almost any page in the later volumes of Beauvoir's autobiography to witness her thinking politically. She admits that before occupation, she did not pay much attention to politics, but living under Nazi domination changed all that. Reflecting their new political awareness, in 1945 Beauvoir and Jean-Paul Sartre founded Les Temps Modernes. Beauvoir remained active on the journal's board until her death in 1986; the current Chief-editor is Claude Lanzmann, Director of Shoah (1985), with whom Beauvoir had an intense intellectual and romantic relationship.

The monthly journal, and Beauvoir and Sartre particularly, were at the center of French intellectual life for several decades. Included in the journal, for example, were significant essays on race relations in the United States, articles condemning the French war in Algeria, analyses of life in the Soviet Union and the Eastern bloc, contributions of authors from the former colonies on race, colonialism and oppression, and analyses of the Arab-Israeli conflict. Les Temps Modernes was the most important intellectual gathering place for political debates and conversations on the 
non-Communist Left during much of Beauvoir's lifetime, although after 1968, existentialism, and particularly Sartre's intellectual dominance on the Left, was significantly challenged, and the journal's influence waned. Nevertheless, directing the business of the journal and meeting activists and writers kept politics, narrowly defined, prominent in Beauvoir's activities and focus. In addition to traveling all over Europe to meet with important Left thinkers and leaders, Beauvoir spent extended periods of time in the United States, Mexico, the Soviet Union, North Africa, Cuba, Brazil, China, Japan and Israel. In their travels, Sartre and Beauvoir met with government officials and dissident groups, all meetings with a strong political agenda. Often, in each of these places, she also met independently with women's groups and feminist associations inspired by The Second Sex.

Given this very active political life, it seems odd that Beauvoir is not more widely recognized as a political thinker. This might be attributed, at least in part, to the dominance of The Second Sex in the reception of Beauvoir's writings, and the unfortunate practice of failing to see feminist theory as a contribution to political theory. Whatever the explanation for this oversight, very little explicit attention has been paid to Beauvoir's political thought until recently (see Marso, 2012a, b). Sonia Kruks' focus in this book on the 'politics of ambiguity' is a welcome and long overdue addition, as was her work (Kruks, 2006) in my and Patricia Moynagh's 2006 co-edited volume, Simone de Beauvoir's Political Thinking.

Highlighting the significance of the concept of ambiguity, Kruks explores Beauvoir's political thought from a philosophical perspective that emphasizes paradox, failure and the antinomies of action in politics. She opens each of her chapters by situating Beauvoir's distinct contributions within contemporary philosophical debates on humanism and post-humanism, oppression, privilege, judgment and the affective dimensions of the desire for revenge. A key feature of the book is the way Kruks situates Beauvoir's contributions within today's philosophical conversations rather than as emerging from the concrete events and political dilemmas experienced by Beauvoir, some of which I listed above.

What will strike readers most powerfully from Kruks' account is the relevance of Beauvoir's writings to contemporary debates in political theory, and the importance of Beauvoir's thought in and beyond her significant contributions in The Second Sex. Working with Beauvoir's writings across her oeuvre, Kruks convincingly documents why Beauvoir should be studied as a political thinker. In the chapter on 'Humanism after Post-humanism', for example, Kruks explains that Beauvoir was just as critical of abstract humanism as many post-structural and postcolonial critics were, but that 'she did not embrace the troubling erasures of "the human" that poststructuralism and posthumanism would often advocate or invite' (p. 26). Most important, Beauvoir attached consciousness to bodies. As Kruks puts it, Beauvoir says that we discover we are 'strange and ambiguous' existents, corporeal beings at the same time free (not strictly determined), as well as constrained by the world in which we find ourselves 'bodily situated' (p. 27). Kruks uncovers what she calls an 'ambiguous humanism' in 
Beauvoir's work, a 'humanism that is critical of itself in the name of humanism' (p. 32). As Kruks summarizes: 'hers is a humanism that acknowledges that conflicts and harm to others, that egregious failures in the pursuit of commendable goals, are inevitable' (p. 53).

Relatedly, Kruks reminds us that Beauvoir is a master of keeping both 'macro' and 'micro' politics in view: women's inferiority, for instance, as documented in The Second Sex, is produced both through location in 'macro' social structures and through 'micro' interpersonal encounters and 'idiosyncratic experiences' (p. 66). Beauvoir recognized embodiment and location in the world as constituting the oppression of groups, as well as affecting individuals, even herself. Kruks explores this in the most intriguing chapter of the book, which is on the politics of confronting, acknowledging and deploying one's privilege. Here, Kruks retells the story of Beauvoir's intervention in the case of Djamila Boupacha (see also Shelby, 2006; Caputi, 2006), a young Algerian militant who was tortured and raped by French army officials in 1960 at the height of the Algerian War of independence. Approaching this intervention through the focus on ambiguity, Kruks evaluates Beauvoir's recognition of her own role in the objectification of Boupacha by using her case to illuminate what was at risk for French democracy in their continuing colonial strategy of occupation and torture. Kruks argues: 'In an ideal world, Beauvoir surely would not have used such a strategy' but that 'her own political interventions bear out her insistence on the necessary ambiguity of action in politics' (p. 118).

An additional compelling feature of this chapter is that Kruks contrasts Beauvoir's self-aware political intervention in order to criticize contemporary feminist writings that advocate individual ethical work on the 'self' and 'personal transformation' in work against racism. As we see in Kruks' reading, Beauvoir sought not to deny, or 'work on', but rather to usefully deploy her privilege. However, this strategy, too, was not without its antinomies. As Kruks shows, the recognition and acknowledgment of privilege can fruitfully, but not non-ambiguously, be deployed for political purposes that we may hope (but never know for sure) will open up enhanced opportunities for freedom. In the case of Boupacha and the newly independent Algeria, things got tricky: after Boupacha's release from prison at the end of the war, Beauvoir denied Boupacha's entreaty for help to remain in France. Beauvoir felt she could not intervene against the government of the newly independent Algeria, even though Boupacha would return to confront severely limited opportunities for women.

The Boupacha chapter stands out because it puts a political event, one that Beauvoir was directly involved in, at the center of the analysis. Although Kruks seeks to highlight Beauvoir's political thinking, we do not learn enough about the actual political events and situations in which Beauvoir was directly involved in her lifetime. Starting with contemporary debates and letting these concerns drive the analysis gives the book an abstract quality, so that we lose the force of the political context and the intensity and quality of Beauvoir's engagement. In short, the political events in which Beauvoir was involved and wrote about do not fully come to life. 
Nevertheless, particularly for its philosophical focus, this book is an important, erudite and thoroughly researched study. It deserves to be read and studied by all scholars interested in political thought generally, as well as for the highly relevant and insightful contributions of Beauvoir.

\section{References}

Caputi, M. (2006) Beauvoir and the case of Djamila Boupacha. In: L. Marso and P. Moynagh. (eds.) Simone de Beauvoir's Political Thinking. Urbana and Chicago, IL: University of Illinois Press.

Kruks, S. (2006) Reading Beauvoir with and against Foucault. In: L. Marso and P. Moynagh (eds.) Simone de Beauvoir's Political Thinking. Urbana and Chicago, IL: University of Illinois Press.

Marso, L. (2012a) Simone de Beauvoir and Hannah Arendt: Judgments in dark times. Political Theory 40(2): 165-193.

Marso, L. (2012b) Thinking politically with Simone de Beauvoir. Theory and Event 15(2).

Shelby, K. (2006) Beauvoir and ethical responsibility. In: L. Marso and P. Moynagh. (eds.) Simone de Beauvoir's Political Thinking. Urbana and Chicago, IL: University of Illinois Press.

Lori Marso

Union College, Schenectady, NY 12308, USA marsol@union.edu 